\section{The mineral content of spring and summer pasture grazed by young growing Thoroughbred in the UK}

Louise Jones, Jennifer Lax and Teresa Hollands

Dodson and Horrell Ltd., Islip, UK

\section{Introduction}

Spring (SP) and summer (SU) pastures contribute 60-100\% (depending on physiological status) of the daily dry matter intake of Thoroughbreds (TB) in the UK. Minerals are an essential component of correct nutrition, particularly for the young growing horse. The mineral content of UK pasture used specifically for young growing TB's has not been fully described in the literature. Factors such as underlying soil type, sward composition, management, fertiliser treatment and stage of maturity will all affect the mineral content of pasture (Beeson et al. 1947, Underwood 1981). The aim of this study was to investigate the variation in the mineral content of spring (March-June, SP) and summer (July-Sept, SU) pastures with regard to meeting the requirements of young growing TB.

\section{Material and methods}

A standardised method was used to collect monthly pasture samples ( $n=200$ (SP), $n=60$ (SU), Crofts and Jefferson 1999). All samples were delivered directly to the laboratory within three hours, where they were frozen at $-18^{\circ} \mathrm{C}$ prior to analysis. Minerals were determined by Inductively Coupled Plasma Mass Spectrometry (ICP-MS, State Chemistry Laboratory 1987). Statistical analysis was performed using Minitab (Hendricksen et al. 1996). The distribution of the data was tested using the Anderson Darley Test of normality. The differences between the mineral content of SP and SU pastures were tested using either T-tests or the non-parametric equivalent Mann-Whitney.

\section{Results}

The mineral contents of SP and SU pasture were significantly different $(p<0.05)$, with the exception of zinc $(p>0.05)$, although the differences were not consistent (Table 1).

\section{Discussion}

Calcium

Month and season significantly $(p<0.05)$ influence the $\mathrm{Ca}$ content of pastures (Fisher et al. 2003, Ganskopp and Bohnert 2003, Poland and Manske 2004). It is reported to be
Table 1 The calcium $(\mathrm{Ca})$, phosphorus $(\mathrm{P})$, magnesium $(\mathrm{Mg})$, potassium (K), copper (Cu) and zinc (Zn) contents of spring (SP) and summer (SU) TB-grazed pastures in the UK.

\begin{tabular}{|l|r|r|r|r|r|r|}
\hline \multirow{2}{*}{ Season } & \multicolumn{7}{|c|}{ Mineral content (/kg dry matter) } \\
\cline { 2 - 8 } & $\mathrm{Ca} \mathrm{g} / \mathrm{kg}$ & $\mathrm{P} \mathrm{g} / \mathrm{kg}$ & \multicolumn{1}{|c|}{$\mathrm{Mg} / \mathrm{kg}$} & $\mathrm{K} \mathrm{g} / \mathrm{kg}$ & $\mathrm{Cu} \mathrm{mg} / \mathrm{kg}$ & $\mathrm{Zn} \mathrm{mg} / \mathrm{kg}$ \\
\hline $\begin{array}{l}\mathrm{SP} \\
\text { mean } \pm \mathrm{sd}\end{array}$ & $6.2 \pm 1.30^{\circ}$ & $3.6 \pm 0.70^{\circ}$ & $1.4 \pm 0.30^{\circ}$ & $26.6 \pm 6.90^{\circ}$ & $7.6 \pm 2.35^{\circ}$ & $28.3 \pm 8.25$ \\
\hline $\begin{array}{l}\mathrm{SU} \\
\text { mean } \pm \mathrm{sd}\end{array}$ & $7.3 \pm 2.00^{\mathrm{b}}$ & $3.1 \pm 0.80^{\mathrm{b}}$ & $1.6 \pm 0.40^{\mathrm{b}}$ & $20.4 \pm 5.60^{\mathrm{b}}$ & $6.4 \pm 2.53^{\mathrm{b}}$ & $27.8 \pm 8.10$ \\
\hline Range & $4.9-9.3$ & $2.3-4.3$ & $1.1-2.0$ & $14.8-33.5$ & $3.8-9.9$ & $19.7-36.5$ \\
\hline requirements & $6.1^{\prime}$ & $3.4^{\prime}$ & $0.8^{\prime}$ & $3^{\prime}$ & $10^{2}$ & $40^{2}$ \\
\hline
\end{tabular}

Different superscripts $=$ significant differences with columns at $p<0.05$.

Based on a rapidly growing 6 month old horse.

Based on all horses irrespective of physiological status.

*Perkin-Elmer ICP-MS VG PQ ExCell (Winsford, Cheshire)

lowest in May, increasing significantly $(p<0.05)$ between July and Sept (Poland and Manske 2004). In addition, high K content in May pastures has been reported to negatively correlate with Ca content (McDonald et al. 2002). In this study 60\% of the SP samples were taken in May, which may account for the significantly $(p<0.05)$ lower Ca in SP compared with SU pastures. Underlying soil type also has a significant $(p<0.05)$ effect on the Ca content of pastures (Ganskopp and Bohnert 2003). In this study $50 \%$ of SU samples were from the Newmarket area, an area overlying calcareous soils. This may explain the higher $\mathrm{Ca}$ content found in SU pastures.

The clover content of ruminant pastures increased in the SU (Weller and Copper 2001), clovers have been shown to have a higher Ca content than grasses (McDonald et al. 2002) and it has been suggested that clover could represent the dominant species in equine pastures in June (Frape 1998). This factor should be considered when examining differences between SU and SP pastures. The effects of fertiliser treatment and weather conditions were not studied; however nitrogen $(N)$ fertiliser has been shown to significantly $(p<0.05)$ reduce the Ca content of pasture (McKenzie and Jacobs 2002), and is commonly used on equine pastures in the SP. The typical published range for UK ruminant pastures is $2.5-5 \mathrm{~g} \mathrm{Ca} / \mathrm{kg}$ DM (McDonald et al. 2002). The results of this study suggested higher upper and lower percentiles $(4.9-9.3 \mathrm{~g} \mathrm{Ca} / \mathrm{kg}$ $\mathrm{DM})$ for equine pastures in the SP and SU in the UK. This closely reflects the Ca content (3.4-16 g/ $/ \mathrm{kg} \mathrm{DM}$ ) of equine pastures in Newmarket (Frape 1998). The geographical biases towards Newmarket are likely to explain these differences in the $\mathrm{Ca}$ ranges between ruminant and equine pastures.

\section{Phosphorous}

The P content of SU pastures has been reported to be less than SP pastures (Grings et al. 1996, Poland and Manske 2004). This is contrary to a study on a single species of grass, tall fescue (Fisher et al. 2003). Although species was not investigated in this study, it is likely to have had a significant influence on $\mathrm{P}$ concentrations in pastures. It is proposed that the significantly $(p<0.05)$ lower $\mathrm{P}$ content of $\mathrm{SU}$ pastures found in this study was a result of a higher proportion of dead plant tissue in July to Sept, which has been shown to contain less $P$ than live plant tissue (Grings et al. 1996). N and superphosphate fertiliser treatment also significantly $(p<0.05)$ increased P concentrations in pastures (Grings et al. 1996, Hendricksen et al. 1996, McKenzie and Jacobs 2002). Fertilisation of equine pastures typically occurs in the SP, this may explain the higher concentrations seen at this time. The upper percentile of the typical range (2.3-4.3g P/kg DM) for SP and 
SU equine pastures in the UK found in this study was greater than that of UK ruminant pastures (2-3.5g P/kg DM) but less than that found on Newmarket equine pastures (2.0-5.4g $\mathrm{P} / \mathrm{kg}$ DM, Frape 1998, McDonald et al. 2002). Differences in the management and fertiliser treatment of pastures may account for these differences.

\section{Magnesium}

The Mg content of ruminant pastures is reported to decrease during the period of active growth in the SP (McDonald et al. 2002) before increasing throughout the growing season until Sept (Grings et al. 1996). Mg is an essential element of chlorophyll and seasonal weather differences influence chlorophyll concentrations. In addition, SP application of $\mathrm{N}$ fertiliser would also have significantly increased $(p<0.05)$ the $\mathrm{Mg}$ content of SP pastures (McKenzie and Jacobs 2002). Although grass species was not studied, it undoubtedly influences the Mg content of pastures (Grings et al. 1996); ryegrasses $x$ fescue hybrids have been reported to contain $44 \%$ more $\mathrm{Mg} / \mathrm{kg}$ DM than standard Italian ryegrass (Frape 1998). In this study the Mg content of pastures was between 1.1 to 2.0 $\mathrm{g} / \mathrm{kg}$ DM, agreeing with that reported for both ruminant pastures and Newmarket equine pastures (1.2-2g Mg/kg DM, Frape 1998, Weller and Copper 2001).

\section{Potassium}

$K$ has been reported to be significantly $(p<0.01)$ lower in SU pastures compared with SP pastures, regardless of species (Fisher et al. 2003, Poland and Manske 2004). The results of this study $(p<0.05)$ agreed with this finding. Increasing plant maturity leads to translocation and leaching of $K$ from the plant tissue (Roche et al. 2000) also, spring application of $N$ and potassium chloride fertilisers has been reported to significantly $(p<0.05)$ increase $K$ content of ruminant pastures (McKenzie and Jocobs 2002, Roche et al. 2000). It is probable that both factors offer an explanation for the seasonal differences found in this study. Stocking densities tend to be lower in the SU, as yearlings are usually housed in preparation for sale. Although the effect of stocking density was not studied, a higher stocking density may account for the higher $\mathrm{K}$ content of SP pastures, as $\mathrm{K}$ will be recycled via the urine. The results of this study suggest a range of $14.8-33.5 \mathrm{~g} \mathrm{~K} / \mathrm{kg}$ DM for UK pastures used for TB breeding-stock during the SP and SU. This is similar to the $15-30 \mathrm{~g} / \mathrm{kg}$ DM reported for ruminant pastures (McDonald et al. 2002).

\section{Copper}

SP pastures have been reported to have a significantly $(p<0.01)$ higher Cu content compared to SU pastures (Fisher et al. 2003) similar results were reported in this study $(p<0.05)$. Pasture Cu content increases following application of nitrogen fertilisers or manure (Gladstones et al. 1986, Keller et al. 2002); although fertiliser treatment was not studied, application is common on equine pastures in the SP. Higher soil temperatures (Brennan et al. 1996) and increasing plant maturity have been shown to reduce copper uptake by plants (Munshower and Neuman 1978, Underwood 1981) this may explain the relationship between $\mathrm{Cu}$ and season in this study. This study found a typical range, 3.8-9.9mg Cu/ $\mathrm{kg}$ DM in the SP and SU on equine pastures in the UK, which was not substantially different to the commonly used values of 4 to $8 \mathrm{mg}$ $\mathrm{Cu} / \mathrm{kg}$ DM used for ruminant pastures (McDonald et al. 2002), although higher values, 4.5 and $12.3 \mathrm{mg} \mathrm{Cu} / \mathrm{kg} \mathrm{DM}$, have been reported on Newmarket equine pastures McKenzie and Jocobs 2002).

Zinc

American studies reported significant $(p<0.01)$ differences in Zn content of SP and SU pastures (Mayland et al. 1987, Fisher et al. 2003) whilst, other studies have found no significant ( $p>0.05$ ) difference (Grings et al. 1996). A decline in the $\mathrm{Zn}$ content in this study was noted between May and July; similarly American studies have shown a decline in $\mathrm{Zn}$ content during July-Aug pasture and an increase in September (Poland and Manske 2004). Thus, the grouping of samples may have masked both monthly and possible seasonal differences. Care should be taken comparing across continents, as seasons may vary. The results from this study, 19.7$36.5 \mathrm{mg} \mathrm{Zn/kg} \mathrm{DM}$, are similar to those already reported in Newmarket equine pastures (21 to $34 \mathrm{mg} \mathrm{Zn/kg}$, Frape 1998) but differ to those reported in ruminant pastures (15$50 \mathrm{mg} / \mathrm{kg}$ DM, McDonald et al. 2002). Low availability of $\mathrm{Zn}$ on pasture overlying calcareous soil may explain these differences.

\section{Conclusion}

The lower percentiles of the ranges for all minerals in SP and $\mathrm{SU}$ pastures, with the exception of $\mathrm{K}$ and $\mathrm{Mg}$, do not meet the minimum requirements of the young growing TB (NRC 1989). This must be corrected through supplementary feeding. SU pasture contains significantly less $\mathrm{K}, \mathrm{Cu}, \mathrm{Zn}$ and $\mathrm{P}$ than SP pasture. This is of particular relevance for horses born late in the season, which are weaned in the summer. These horses will require a higher level of mineral supplementation than those weaned in the SP. The published ranges of $\mathrm{Ca}, \mathrm{P}, \mathrm{Cu}$ and $\mathrm{Zn}$ in ruminant pastures do not accurately describe the ranges for equine pasture in the UK, particularly in the Newmarket area. This must be considered when formulating diets for young growing TB. Further investigation is needed to determine the effect of underlying soil type, sward composition, management, fertiliser treatments, and stage of grass maturity on the mineral content of pasture used by young growing TB.

\section{Acknowledgements}

Thanks to Derek Cuddeford and Dr John Lowe for their constructive criticism of this abstract.

\section{References}

Beeson K. C., Gray L. and Adams M. B. (1947): The absorption of mineral elements by forage plants. Journal of the American Society of Agronomy 39, 356 
Brennan R. F., Gartrell J. W. and Robson A. D. (1996): Reactions of copper with soil affecting its availability to plants. lii Effect of Incubation temperatures. Journal of Soil Research 22, 165-172Crofts A. and Jefferson R. G. editors. (1999): The lowland grassland management handbook. 2nd ed. London: English Nature

Fisher A. E., Gill W. W., Lane C. D., Jones D. K., Neel J. B. and Richards C. J. (2003): Focus on minerals for beef cattle: Part 2 Deficiencies and imbalances revealed in Tennessee tall fescue forage systems. Tennessee: University of Tennessee

Frape D. (1998): Equine Nutrition and Feeding, 2nd edition. Oxford: Blackwell Science Ltd.

Gladstones J. S., Loneragan J. F. and Simmons W. J. (1986): Mineral elements in temperate crop and pasture plants. Australian Journal of Agricultural Research 26, 113-126

Ganskopp D. and Bohnert D. (2003): Mineral concentration dynamics among 7 northern Great Basin grasses. Journal of Range Management 56, 174-184

Grings E. E., Haferkamp M. R., Heitschmidt R. K. and Karl M. G.(1996): Mineral dynamics in forages of the Northern Great Plains. Journal of Range Management 49, 234-240

Hendricksen R. E., Gilbert M. A. and Punter L. D. (1996): Effect of superphosphate application on macro-nutrient and micro-nutrient concentrations in grazed stylo-native grass pasture in tropical Australia. Australian Journal of Agricultural Research 43, 1725 1738

Keller C., McGrath S. P. and Dunham S. J. (2002): Trace metal leaching through a soil-grassland system after sewage sludge application. Journal of Environmental Quality 31, 1550-1560

Mayland H. F., Kramer T. R. and Johnson W. T. (1987): Trace elements in the nutrition and immunological response of grazing livestock. Grazing Livestock Nutrition Conference Proceedings. Wyoming: University of Wyoming

McDonald P., Edwards R. A., Greenhalgh J. F. D. and Morgan C. A. (2002): Animal Nutrition, 6th edition. Essex: Pearson Education Ltd.

McKenzie F. R. and Jacobs J. L. (2002): Effects of application of nitrogen fertiliser on concentrations of $\mathrm{P}, \mathrm{K}, \mathrm{S}, \mathrm{Ca}, \mathrm{Mg}, \mathrm{Na}, \mathrm{Cl}, \mathrm{Mn}, \mathrm{Fe}$, $\mathrm{Cu}$ and $\mathrm{Zn}$ in perennial ryegrass/ white clover pastures in southwestern Victoria, Australia. Grass and Forage Science 57, 48-53
Munshower F. F. and Neuman D. R. (1978): Elemental concentrations in native range grasses from the northern great plains of Montana. Journal of Range Management 31, 145-149

NRC (1989): Nutrient requirements of horses. 5th edition. Washington, D.C.: National Academy PressPoland W. W. and Manske L. L. (2004): Effect of year and season on mineral concentrations of cool and warm season grasses from native ranges. North Dakota: Dickinson Research Extension Centre

Roche J. R., Dalley D., Moate P., Grainger C., Hannah M., O'Mara F. and Rath M. (2000): Variation in the dietary cation-anion difference and the acid-base balance of dairy cows on a pasturebased diet in south-eastern Australia. Grass and Forage Science $55,26-36$

State Chemistry Laboratory. Method 013 (1987): determination of $\mathrm{Ca}, \mathrm{Mg}, \mathrm{Na}, \mathrm{K}, \mathrm{S}, \mathrm{P}, \mathrm{Fe}, \mathrm{Cu}, \mathrm{Zn}$ and $\mathrm{Mg}$ in plant material by inductively coupled plasma-mass spectrometry. Werribee: Department of Natural Resources and Environment

Underwood E. J. (1981): The mineral nutrition of livestock. Slough: Commonwealth Agricultural Bureaux

Weller R. F. and Cooper A. (2001): Seasonal changes in the crude protein concentrations of mixed swards of white clover/ perennial ryegrass grown without fertiliser $\mathrm{N}$ in an organic farming system in the United Kingdom. Grass and Forage Science 56, 92-95

L. Jones

Dodson and Horrell Ltd.

Kettering Road

Islip, Northamptonshire NN14 3JW

United Kingdom

ljones@dodsonandhorrell.com 